\title{
Trophic cascades in seagrass meadows depend on mesograzer variation in feeding rates, predation susceptibility, and abundance
}

\author{
Rebecca J. Best* ${ }^{*}$ John J. Stachowicz \\ Evolution and Ecology, University of California Davis, One Shields Avenue, Davis, California 95616, USA
}

\begin{abstract}
Seagrasses provide important habitat for fishes and invertebrates but are declining around the globe, often due to overgrowth by algae. One hypothesis for this overgrowth is that overfishing of top consumers has led to greater numbers of small predatory fishes that reduce the abundance of mesograzers. This trophic cascade hypothesis requires that the same species that control algal biomass are also susceptible to fish predation. While mesograzers are known to vary in their feeding rates on algae and seagrasses, much less is known about variation in predation susceptibility and how this is related to grazing abilities. For 6 common mesograzers from Bodega Harbor, California, USA, we assessed feeding rates on macroalgae (Ulva spp.), epiphytic microalgae, and eelgrass. We then assessed predation susceptibility using juvenile cabezon Scorpaenichthys marmoratus in tanks of eelgrass habitat with and without Ulva. We found that the fastest consumers of all 3 primary producers were the least susceptible to predation. This appeared to be due to predator avoidance strategies; fish consumed visible caprellids at a higher rate than the larger consumers, which were either better camouflaged or able to avoid predation by building tubes within the macroalgae. Using our feeding and predation rates, along with relative abundances from field surveys, we calculated the expected trophic cascade effect with and without grazer species differences. Because fish predation was skewed towards the most abundant but least important (per capita) grazers, incorporating trait variation led to a 50 to $80 \%$ reduction in expected trophic cascade effects. Examining other seagrass communities for either similar grazer species or a similar mismatch between feeding rates and predation susceptibility may improve our understanding of the variation in trophic cascade effects across systems.
\end{abstract}

KEY WORDS: Epiphytes $\cdot$ Overgrowth $\cdot$ Amphipod $\cdot$ Eelgrass

Resale or republication not permitted without written consent of the publisher

\section{INTRODUCTION}

Globally, seagrass ecosystems provide habitat for a diversity of fish and crustaceans as well as a number of ecosystem services, including sediment stabilization and nutrient cycling (Hemminga \& Duarte 2000, Orth et al. 2006, Valentine \& Duffy 2006). They are also declining at an accelerating rate (Waycott et al. 2009), often in association with overgrowth by microand macroalgae, which grow rapidly and prevent adequate light from reaching seagrass blades (Va- liela et al. 1997, McGlathery 2001). Such blooms of algae may be increasing due to eutrophication of coastal waters or to food web alterations that reduce the numbers of the invertebrate grazers that regulate algal abundance (Hughes et al. 2004, Heck \& Valentine 2007). This hypothesis that trophic cascades are partly responsible for global seagrass declines is based on evidence that grazers such as crustaceans and gastropods can have substantial impacts on algal abundance and on the idea that overfishing of top predators could increase the abundance of the fish 
that eat these grazers (Heck \& Valentine 2007). In support of this hypothesis, recent field experiments have shown that in regions of Scandinavia with high densities of invertivorous fish, fish exclusion can lead to increases in grazer density and decreases in algae (Moksnes et al. 2008, Eriksson et al. 2009, Baden et al. 2010, Sieben et al. 2011). This parallels evidence for similar fish-invertebrate-periphyton trophic cascades in freshwater benthic systems (Power 1990, Bronmark et al. 1992, Martin et al. 1992, Vonesh et al. 2009).

Over a wide range of seagrass systems, however, the effect of predators on algal growth and seagrass production appears to be variable. Pinfish, an important consumer of mesograzers in Florida seagrass systems (Nelson 1979, Stoner 1979), will also consume epiphytic algae (Gacia et al. 1999, Heck et al. 2000), and (under nutrient enrichment) seagrass itself (Heck et al. 2006). Such omnivory has been widely documented as preventing trophic cascades (Persson 1999, Bruno \& O'Connor 2005, Finke \& Denno 2005, Eriksson et al. 2010). Along with this vertical heterogeneity in trophic structure, differences among species within a trophic level can also affect the potential for trophic cascades (Persson 1999). For example, in a large Caribbean food web, tri-trophic linkages between a producer, consumer, and predator species were less likely to contain 2 strong interactions than if assembled by chance (Bascompte et al. 2005). Instead, some consumers had strong interactions with predators, while others had strong interactions with prey. In cases in which a single consumer taxon was strongly linked to both a producer and a predator, omnivory was more likely (Bascompte et al. 2005). This mismatch between the most effective consumers and those most susceptible to predation may be an important mechanism for food web stability.

In seagrass systems, invertebrate grazers vary in their feeding rates on microalgae, macroalgae, and seagrasses themselves (Duffy \& Hay 1991, Duffy et al. 2001, Raberg \& Kautsky 2007, Jaschinski \& Sommer 2008, Hughes et al. 2010). Although much less is known about species-specific predation susceptibility, species do vary in ways that may affect their visibility and escape success, such as size, coloring, and behavior. For example, caprellid amphipods cling to seagrass blades and are very slow swimmers, whereas ampithoid amphipods hide in tubes between seagrass blades or in folds of macroalgae. In this study, we assessed for the first time both variation in feeding rates and variation in predation susceptibility for the same grazer species. We also mea- sured the abundance of these species in field surveys. We then used these data to show how variation in these traits alters the potential for trophic cascades to increase overgrowth of the seagrass Zostera marina by macroalgae or epiphytic microalgae. We argue that predicting the effect of trophic cascades on algal abundance and seagrass photosynthesis depends on the extent to which the most important consumers of algae are also the most susceptible to fish predation.

\section{MATERIALS AND METHODS}

\section{Study system}

We conducted our study in Bodega Harbor, California, USA $\left(38^{\circ} 19.110^{\prime} \mathrm{N}, 123^{\circ} 04.294^{\prime} \mathrm{W}\right)$. Bodega Harbor contains several large intertidal and sub-tidal beds of Zostera marina (hereafter eelgrass), as well as extensive mud flats. Eelgrass beds reach maximum density in summer and fall, with 100 to 250 shoots $\mathrm{m}^{-2}$ and average shoot length ranging from 80 to $130 \mathrm{~cm}$. Water temperature ranges from $6^{\circ} \mathrm{C}$ in the winter to $24^{\circ} \mathrm{C}$ in shallow beds during low tides in summer and fall (nearby ocean temperatures reach only $17^{\circ} \mathrm{C}$ ). The warm temperatures and increased light influx between May and October correlate with increased growth of epiphytic microalgae and Ulva spp. macroalgae (hereafter Ulva), both of which compete with eelgrass for light and reduce eelgrass growth (Olyarnik 2008, Hughes et al. 2010).

Mesograzers in this system also peak in summer and fall, and include 11 common amphipod species, 2 isopods, and 4 mollusks. While one of the mollusks, the sea hare Phyllaplysia taylorii, is an important grazer of epiphytic microalgae (Hughes et al. 2010), it is more patchily distributed and lower in abundance than the crustacean grazers in this system. After measuring feeding rates on eelgrass, Ulva, and microalgae for each of the amphipod and isopod species in our system, we selected 6 species for further study. These species vary in their taxonomic group, origin, size, and behavior (Table 1), as well as their abundance and feeding rates, but include the most widely distributed mesograzers in Bodega Harbor eelgrass beds and the species with the fastest consumption rates on all 3 potential primary producers (R. Best unpubl. data). Subsets of all of these mesograzer species have also been reported from several other northeastern Pacific estuaries, including Boundary Bay in British Columbia, Willapa Bay in Washington, Coos Bay in Oregon, and 
Table 1. Description of the grazer species studied

\begin{tabular}{|lcccccc|}
\hline Species & Order & Family & Origin & $\begin{array}{c}\text { Max. length } \\
\text { (mm) }\end{array}$ & $\begin{array}{c}\text { Max. width } \\
(\mathrm{mm})\end{array}$ & Behavior \\
\hline Idotea resecata & Isopoda & Valvifera & Native & 45 & 8 & Swimming/clinging \\
Caprella californica & Amphipoda & Caprellidae & Native & 30 & 1 & Clinging \\
Caprella mutica & Amphipoda & Caprellidae & Introduced & 35 & 1.5 & Clinging \\
Ampithoe lacertosa & Amphipoda & Ampithoidae & Native & 25 & 7 & Tube building \\
Ampithoe sectimanus & Amphipoda & Ampithoidae & Native & 12 & 4 & Tube building \\
Ampithoe valida & Amphipoda & Ampithoidae & Introduced & 13 & 4 & Tube building \\
\hline
\end{tabular}

Humboldt Bay, Tomales Bay, and San Francisco Bay in California.

The most abundant fish predators in Bodega Harbor include juvenile cabezon Scorpaenichthys marmoratus, juvenile perch (Embiotocidae; adults are much less abundant), rockfish Sebastes spp., sanddab Citharichthys sordidus, 3-spined stickleback Gasterosteus aculeatus, and in some years pipefish Syngnathus spp. and staghorn sculpin Leptocottus armatus (Bozdech 2004, Dowd 2006, Yip 2006). We chose to study juvenile cabezon because they are relatively abundant in Bodega Harbor from early spring to late fall, when they migrate to rocky reef habitat for adulthood, and have previously been shown to consume amphipods and isopods (as well as larger prey) in our system (Lewis 2002, Yip 2006, J. Hobbs pers. comm.). They are also found in other northeastern Pacific estuaries, and show annual variation in density that is thought to be driven by oceanographic conditions and variability in recruitment success (Wilson et al. 2008). This is in contrast to systems in which changes in the density of invertivorous fish may be driven by harvesting of top predators; we are investigating only the 3-level trophic relationship between small fish, mesograzers, and primary producers.

Juvenile cabezon grow larger than other abundant fish in the system, and have an especially large gape for their length, which should make them most able to consume our largest grazers. Gut-content analysis from Bodega Harbor is consistent with this: only cabezon had Idotea and a substantial fraction of amphipods in their guts, whereas stickleback, perch, sculpin, and sanddab consumed mostly Heptacarpus shrimp and/or polychaetes (Yip 2006). Given that adult mesograzers have a larger effect on algal biomass than juveniles (Moksnes et al. 2008), and that adults of the most important grazers in our system are large relative to gape size for most of these fish species, juvenile cabezon appear to be the most likely to consume these individuals.

\section{Feeding trials}

We measured species-specific feeding rates using $48 \mathrm{~h}$ no-choice feeding trials. We placed 2 ind. of a single grazer species in $250 \mathrm{ml}$ plastic cups filled with seawater, and after $24 \mathrm{~h}$ starvation, added a single food source of either eelgrass, Ulva, or microalgae. Because we were gathering feeding rate data as part of a larger study including several other species of grazers, we used a total of 4 separate trials, 2 in the summer of 2009 and 2 in the summer of 2010, with the replicates for each combination of species with food type split between at least 2 trials. This also served to ensure that our results reflect true differences between species that hold over temporal variation in food quality. We used a total of 10 replicate cups per food type per grazer species, as well as 10 no-grazer controls for each food in each trial to account for growth or decay. These trials were conducted in an indoor wet lab on a $12 \mathrm{~h}$ light: $12 \mathrm{~h}$ dark cycle.

For the eelgrass and Ulva replicates we used approximately $2 \mathrm{~cm}^{2}$ of food, and measured consumption as change in wet weight, after adjusting the starting weight by the average percent change in control cups for that food in that trial. This amount of food was never completely depleted by the grazers. For the microalgae replicates we used $9 \mathrm{~cm}^{2}$ pieces of window screen covered with microalgae and measured consumption as the reduction in chlorophyll relative to no-grazer controls for that trial. We obtained the microalgae by anchoring sheets of window screen (1 mm mesh size) on a horizontal frame within an eelgrass bed in Bodega Harbor for $2 \mathrm{wk}$ prior to the feeding trials, cutting the sheets into $9 \mathrm{~cm}^{2}$ pieces with even coverage of algae, and then randomly assigning these pieces to treatment and control cups.

To measure chlorophyll concentrations we froze the window screen in individual vials and extracted and calculated chlorophyll $a, b$, and $c$ according to Parsons et al. (1984), using $10 \mathrm{ml}$ of methanol/acetone/ de-ionized water (45:45:10) as the extraction reagent 
(Duffy \& Harvilicz 2001), and a Beckman Coulter Spectrophotometer. Because change in chlorophyll a (hereafter chl a) was highly correlated with change in total chlorophyll, and represented most of the total, we simply used the decrease in the chl a concentration as our relative measure of grazing rate on epiphytic algae. Because we could not measure chlorophyll for individual replicates before and after feeding, we also measured chlorophyll abundance on 10 randomly selected pieces at the trial outset (the pre-trial control). We found that average chlorophyll was significantly higher in the control cups at the end of the trial than in this pre-trial control group, and therefore used only the final control measurement as a representation of average initial chlorophyll level plus growth.

\section{Predation trials}

We measured species-specific susceptibility to fish predation in $38 \mathrm{l}(50 \mathrm{~cm}$ long $\times 25 \mathrm{~cm}$ wide $\times 30 \mathrm{~cm}$ tall), flow-through, outdoor aquaria planted with 15 shoots of eelgrass collected from Bodega Harbor, cleaned of all epiphytes and epifauna, cut to $30 \mathrm{~cm}$ in length, and anchored in clean sand. This density of shoots $\left(120 \mathrm{~m}^{-2}\right)$ is within the range of observed field densities but was low enough to facilitate recovery of all grazers at the end of the experiment. Because some of the grazer species are known to build tubes in Ulva to reduce vulnerability to fish predation (Olyarnik 2008), we assessed predation (1) with eelgrass only, and (2) with eelgrass plus $18 \mathrm{~g}$ wet weight of Ulva, added in 3 separate pieces anchored into the sand. We surrounded each tank with a double layer of shade cloth to reduce light to natural levels.

To each tank we added 30 grazers: a mix of 5 ind. of each of our 6 grazer species (Table 1). This density ( 240 ind. $\mathrm{m}^{-2}$ ) is well within the middle $50 \%$ of field observations of the combined density of these 6 species, based on the July and September field sampling we describe below. After allowing the grazers $24 \mathrm{~h}$ to acclimate and choose their microhabitat, we added a single juvenile cabezon Scorpaenichthys marmoratus (hereafter cabezon) of recorded length (range: 8 to $11 \mathrm{~cm}$ ) and allowed it to feed for $12 \mathrm{~h}$ of daylight. Cabezon field density ranges from 0 to $0.2 \mathrm{~m}^{-2}$ of eelgrass bed (Yip 2006), so only a single fish was used per tank. Prior to the predation trials, we held all cabezon in tanks of equal densities, with natural habitat, and fed them a standardized diet of frozen squid each day, except for a $24 \mathrm{~h}$ starvation period preceding the trial. Because cabezon are diurnal, we measured their predation rates during $12 \mathrm{~h}$ of daylight to represent a daily rate.

Over 3 consecutive trial periods during September 2010, we conducted 10 treatment replicates (with fish) and 5 control replicates (without fish) for each habitat type. An independent but identically maintained group of fish was used in each trial. At the end of each trial we sieved all water, vegetation, and sand to recover and identify remaining grazers. We adjusted for species differences in probability of recovery independent of predation by subtracting the average number of each species missing from controls from the number eaten in each treatment replicate for that habitat type. The number missing from controls was never more than 1, with an average of 0.4 ind. for the treatment without Ulva and 0.3 with Ulva.

We chose to assess species-specific predation rates using a mixed community of grazers because we wanted to measure the choices fish might make in the mixed communities they encounter in the field. However, we also conducted single species trials for 5 of the 6 grazer species (all but Ampithoe sectimanus) using methods identical to those described above, but with 10 grazers of a single species and 3 replicates per species per habitat treatment. These trials were conducted in August 2010, using fish maintained in the same way as those in the mixed grazer trials. To test the extent to which relative predation rates depend on community composition, we regressed the relative feeding rates from these single species trials on the feeding rates in the mixed species trials. If the order of increasing predation susceptibility between species is consistent between the 2 types of trials, we should see a strong positive relationship. If, however, predation susceptibility depends on the other choices that cabezon have available, i.e. the composition of the grazer community, then we might see no relationship or a negative relationship.

\section{Field sampling}

In addition to variation in feeding rates and predation susceptibility, grazer species vary in their relative abundance. This further constrains both the potential of individual species to control primary producers and the probability they will be consumed by fish predators. To account for this, we measured abundance of all grazer species at 5 Bodega Harbor eelgrass beds in July and September (both within the period of maximum fish abundance) of 2009 and 
2010. At each site, 5 replicate samples were taken $10 \mathrm{~m}$ apart along a transect, in approximately $0.6 \mathrm{~m}$ of water. To sample we collected a vertical core of the water column using a fine mesh bag $(<500 \mu \mathrm{m})$ affixed to a flexible $30 \mathrm{~cm}$ diameter hoop, capturing all vegetation and animals and transporting the sample bags to the lab. We then cleaned each blade of eelgrass and algae of grazers, collected the grazers on a $1 \mathrm{~mm}$ sieve, identified and counted adults of each species, and converted this to number per $\mathrm{m}^{2}$.

To characterize the distribution of algae in our system we cleaned, dried, and weighed all pieces of Ulva in our samples, and converted this to weight per $\mathrm{m}^{2}$. We also determined the density of microalgae by randomly selecting 4 full leaves from each sample, scraping, filtering, drying, and weighing all epiphytes from these leaves, and dividing the dried weight by the leaf surface area.

\section{Analysis}

Our first objective was to determine if the most important consumers were also the most susceptible to fish predation. To identify differences between grazers in feeding rates and predation susceptibility we used mixed effects models. For the feeding rate data, we used 1 model for each primary producer (Ulva, eelgrass, and microalgae), with amount eaten per ind. per $24 \mathrm{~h}$ as the response variable, grazer species as the fixed effect, and trial as the random effect. For the predation data, we used 1 model for each habitat type (with or without Ulva), with number of individuals eaten as the response variable, grazer species as the fixed effect, and both tank and trial as random effects. We also included fish length as a covariate to account for variation in predation intensity or preferences associated with fish size.

We conducted these analyses in SAS (SAS Institute 2008) using the MIXED procedure with the Kenward Rogers method for estimating denominator degrees of freedom (Littell et al. 1996). To identify significant differences between multiple grazer species while maintaining an experiment-wise $\alpha$ of 0.05 we used a Tukey-Kramer adjustment, and to test the significance of random effects we used likelihood ratio tests. All residuals were checked for adherence to assumptions of normality and equal variance and no transformations were necessary.

Using a mixed model framework to analyze the predation data allowed us to calculate speciesspecific predation rates while factoring out variation due to multiple trials and to individual fish, which is essential for the further analyses described below. It also provided one way to test for significant differences between predation rates by using tank as a random effect to account for non-independence between the multiple species in each tank. However, multiple-choice feeding trials can carry an additional problem of negative correlations among observations within a single experimental unit (Lockwood 1998), which can arise when the time spent consuming individuals of one species translates directly into fewer consumed of another species. We therefore also conducted a rank transformation to remove these correlations. We ranked all observations in the analysis regardless of block, and then analyzed the ranks in a randomized complete block ANOVA (Conover \& Iman 1981, Iman et al. 1984). This method has far greater power than other rank-based methods when data are normally distributed (Iman et al. 1984) and has recently been used in similar studies of diet selection in seagrass systems (Prado \& Heck 2011). We conducted this analysis for each habitat type in SAS (SAS Institute 2008) using the RANK and GLM procedures, with tank as the block, grazer species as the effect, and again with a Tukey-Kramer adjustment for multiple comparisons (Conover \& Iman 1981).

Our second objective was to compare the expected trophic cascade effect of fish predation on primary producers with or without information on grazer trait variability (feeding rate, predation susceptibility, and abundance). To do this, we used the least-squares mean estimates of feeding and predation rates, as well as average field abundance. To calculate average abundance in field samples for each species we again used a mixed effects model, with abundance as the response variable, grazer species as the fixed effect, and sampling period and eelgrass bed as the random effects. To meet assumptions, we log-transformed abundance and then back-transformed least squares means for presentation.

Under each of 4 scenarios, we calculated the amount of each primary producer (eelgrass, Ulva, and microalgae) that would no longer be removed due to consumption of grazers by a single cabezon. In each case, we first determined how many individuals of each of the 6 grazer species would be eaten per day in that scenario. We then multiplied the number eaten by that grazer species' daily per capita feeding rate. Finally, we summed these products across all 6 species. Our objective here was to compare the relative trophic cascade effect that would be expected with or without accounting for grazer trait differences. We did not attempt to calculate absolute algal biomass remaining in the field because this would 
require additional data on predator abundance and primary producer abundance and growth rates. Important assumptions underlying these calculations (i.e. that feeding on each primary producer is independent of the other primary producers, and that both species-specific predation rates and total number of grazers eaten are independent of grazer community composition) are evaluated in the 'Results'. The scenarios are described in order of increasing incorporation of variability among grazer species. Sample calculations from each scenario are given in Table A2 in Appendix 1. The scenarios are as follows:

(1) All grazer species are equal. The number of each grazer species eaten is the average total number of grazers eaten divided by the 6 species. The feeding rate for each species is the average of all 6 grazer species' feeding rates.

(2) Grazer species vary in their feeding rates and susceptibility to predation. The number of each grazer species eaten is the species-specific mean predation rate determined in this study. The feeding rates for this and the 2 following scenarios are the speciesspecific mean feeding rates determined in this study.

(3) Grazer species vary in abundance and feeding rates. The number of each grazer species eaten is the average total number of grazers eaten multiplied by the proportional abundance of that grazer (where proportional abundance is the average field abundance of the 6 grazer species scaled to sum to 1). This assumes grazers are eaten as they are encountered, and predation susceptibility depends only on relative abundance. Predation susceptibility on an individual basis is equal across species.
(4) Grazer species vary in abundance, feeding rate, and susceptibility to predation. The number of each grazer species eaten is the species-specific mean predation rate multiplied by its relative abundance, and scaled so that the rates sum to the average total number of grazers eaten. Predation susceptibility in this scenario is thus jointly determined by the relative abundance and the relative predation rates determined in this study.

\section{RESULTS}

\section{Variation in feeding and predation rates}

For all 3 foods, feeding rates were significantly different across the 6 grazer species, and were not affected by variation among trials (Table 2). The order of the grazers' feeding rates also varied among the 3 foods (Fig. 1A-C). Ampithoe lacertosa was by far the fastest consumer of macroalgae (Ulva), but only an average grazer of eelgrass and the second fastest consumer of microalgae. Idotea resecata was the fastest consumer of eelgrass and microalgae. The introduced species $A$. valida was a relatively important consumer of eelgrass but not algae. On the low end of the spectrum, Caprella californica and the introduced C. mutica were the slowest consumers of all 3 foods, and consumed only microalgae at a rate significantly greater than zero.

Grazer species also showed significant variation in predation susceptibility, both with and without Ulva

Table 2. Statistical significance of grazer variation in feeding rates, predation susceptibility, and abundance. GLMM: general linear mixed model on number eaten per day for each species. Significant $p$-values $(p<0.05)$ are in bold

\begin{tabular}{|c|c|c|c|c|c|c|}
\hline Response variable & Fixed effect & df & $F$ & $\mathrm{p}$ & $\begin{array}{c}\text { Random } \\
\text { effect }\end{array}$ & $\mathrm{p}$ \\
\hline \multicolumn{7}{|l|}{ Feeding rate } \\
\hline Ulva (mg ind..$\left.^{-1} \mathrm{~d}^{-1}\right)$ & Grazer species & 5,54 & 105.52 & $<0.0001$ & Trial & 1 \\
\hline Eelgrass $\left(\mathrm{mg}\right.$ ind.$\left.^{-1} \mathrm{~d}^{-1}\right)$ & Grazer species & 5,54 & 16.48 & $<0.0001$ & Trial & 1 \\
\hline Microalgae ( $\mu \mathrm{g}$ chl $a$ ind..$\left.^{-1} \mathrm{~d}^{-1}\right)$ & Grazer species & 5,54 & 107.82 & $<0.0001$ & Trial & 0.8 \\
\hline \multicolumn{7}{|c|}{ Predation rate with Ulva (no. fish ${ }^{-1} \mathrm{~d}^{-1}$ ) } \\
\hline GLMM & Grazer species & 5,51 & 3.85 & 0.005 & Trial & 0.04 \\
\hline GLMM & Fish length & 1,53 & 3.65 & 0.06 & Tank & 0.2 \\
\hline Rank-transformation test & Grazer species & 5,45 & 3.45 & 0.01 & & \\
\hline \multicolumn{7}{|c|}{ Predation rate without Ulva (no. fish ${ }^{-1} \mathrm{~d}^{-1}$ ) } \\
\hline GLMM & Grazer species & 5,53 & 6.17 & $<0.0001$ & Trial & 0.5 \\
\hline GLMM & Fish length & 1,53 & 0.21 & 0.6 & Tank & 0.8 \\
\hline Rank-transformation test & Grazer species & 5,45 & 6.76 & $<0.0001$ & & \\
\hline Abundance $\left(\text { no. } \mathrm{m}^{-2}\right)^{\mathrm{a}}$ & Grazer species & 5,552 & 187.12 & $<0.0001$ & $\begin{array}{l}\text { Sampling period } \\
\text { Site }\end{array}$ & $\begin{array}{c}0.01 \\
<<0.0001\end{array}$ \\
\hline${ }^{a} \log$ transformed for analysis & & & & & & \\
\hline
\end{tabular}




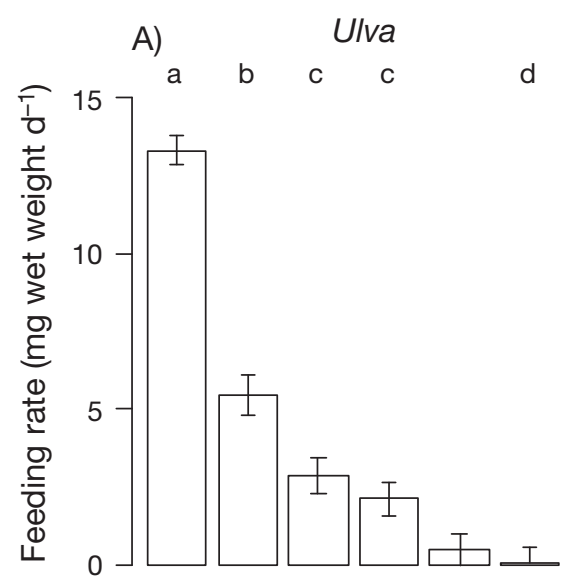

D) With Ulva and eelgrass

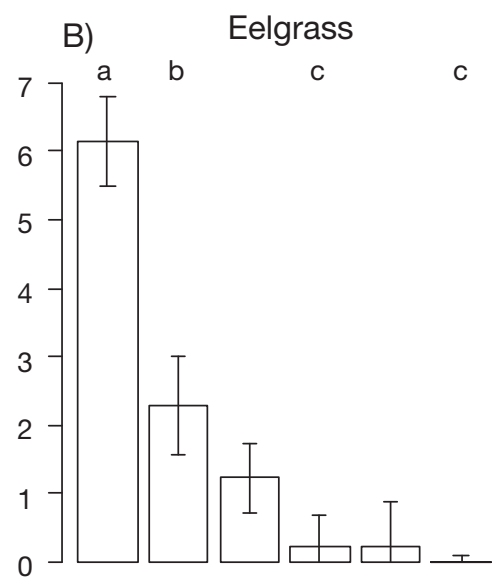

E) With eelgrass

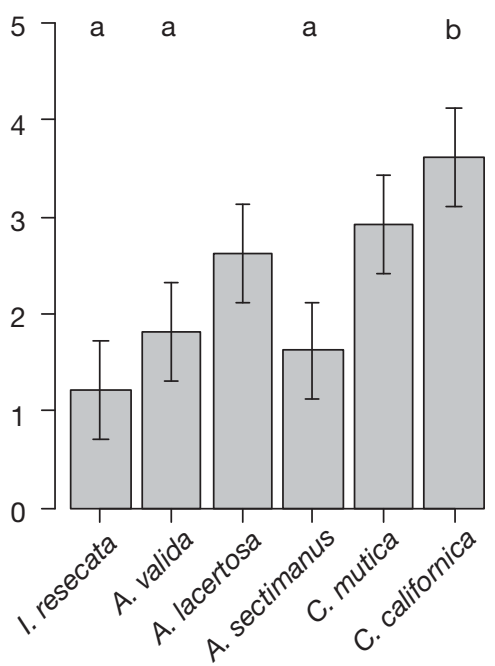

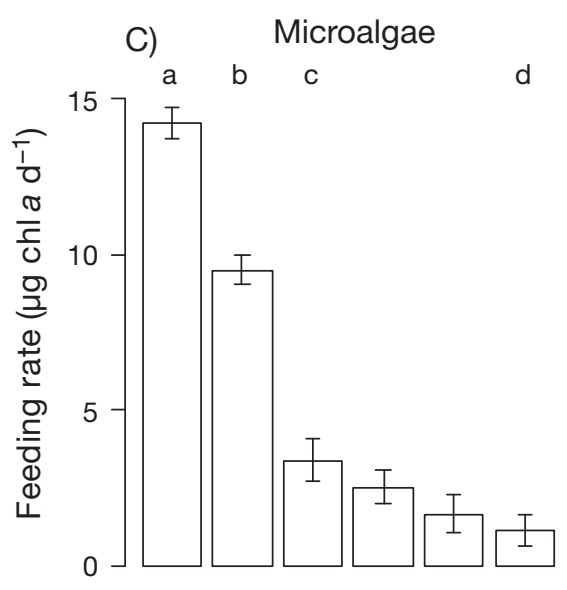

F) With eelgrass

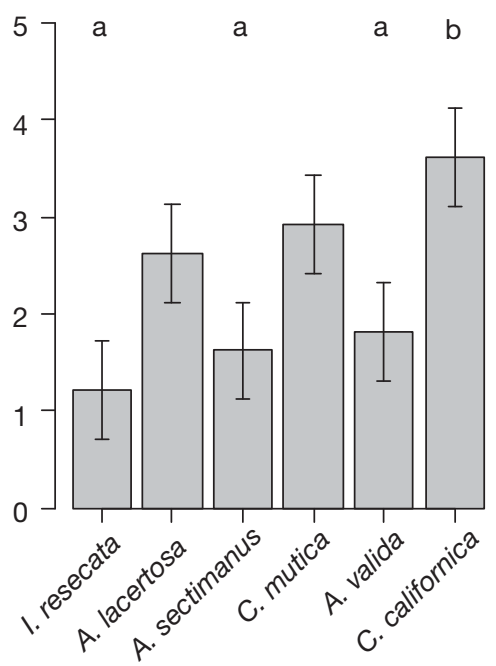

Fig. 1. Species-specific feeding and predation rates of the 6 mesograzer species studied. Top: (A, B, C) show feeding rates on Ulva, eelgrass, and microalgae in decreasing order for that food. Below: (D, E, F) show predation rates in the same order (D: predation rates with Ulva present; E, F: predation rates with Ulva absent). Letters indicate significant differences between species (which for panels (D, E, F) are supported by multiple comparison tests on both the untransformed and rank-transformed data); species without a letter are intermediate. Error bars are $\pm 1 \mathrm{SE}$ from the untransformed mixed model analyses. For full species names and characteristics see Table 1

(Table 2). To identify the correspondence between feeding rate and predation susceptibility, we show the grazer species ordered according to feeding rate for each food (Fig. 1A-C), and present the predation rates for the same species in that order below (Fig. 1D-F). For this comparison, we show the predation rates with Ulva present for comparison to feeding rates on Ulva, and the predation rates without Ulva for comparison to feeding rates on eelgrass and microalgae.

With Ulva present, all 3 Ampithoe species and Idotea resecata experienced less predation than $\mathrm{Ca}$ prella californica, with $C$. mutica showing an intermediate predation rate (Fig. 1D). This means that in cases where Ulva is the dominant competitor of eelgrass, the species most able to control Ulva should be the least susceptible to predation (Fig. 1A,D).

When Ulva was absent, predation susceptibility was lowest for the most important consumers of both eelgrass and epiphytic microalgae. The species with the fastest consumption of eelgrass (Idotea resecata and Ampithoe valida, Fig. 1B) showed significantly lower predation susceptibility than the 2 Caprella species, which did not consume eelgrass at a significant rate (Fig. 1E). Similarly for microalgae, the species with the highest consumption rates had somewhat lower predation rates (Fig. $1 \mathrm{C}, \mathrm{F}$ ). Overall, this trend appears to hold across the 3 columns of Fig. 1; 
the most important consumers were the least susceptible to fish predation.

Finally, we found that the relative predation rates measured in our mixed species trials followed the same pattern in our single species predation trials (Fig. 2). The presence of Ulva did not affect the slope of this relationship $(p=0.7)$ but did marginally affect the intercept $(p=0.06)$ by reducing total predation for both single and mixed trials. Overall, there was a strong positive relationship between the predation rates on each species alone and in mixture $\left(F_{1,6}=\right.$ 25.21, $\mathrm{p}=0.002, \mathrm{R}^{2}=0.81$ ).

\section{Field abundance}

In addition to variation in feeding and predation rates, the 6 grazer species in our study also showed substantial differences in abundance (Fig. 3). The native caprellid Caprella californica was by far the most abundant, followed by Ampithoe lacertosa and Idotea resecata, which were both significantly more abundant than the remaining 3 species. Grazer species differences in abundance were highly significant $(\mathrm{p}<0.0001)$ despite the significant random effects of both time and site on abundance (Table 2). We used the mean species abundances over all samples, but using the abundances from any particular time period yields similar results.

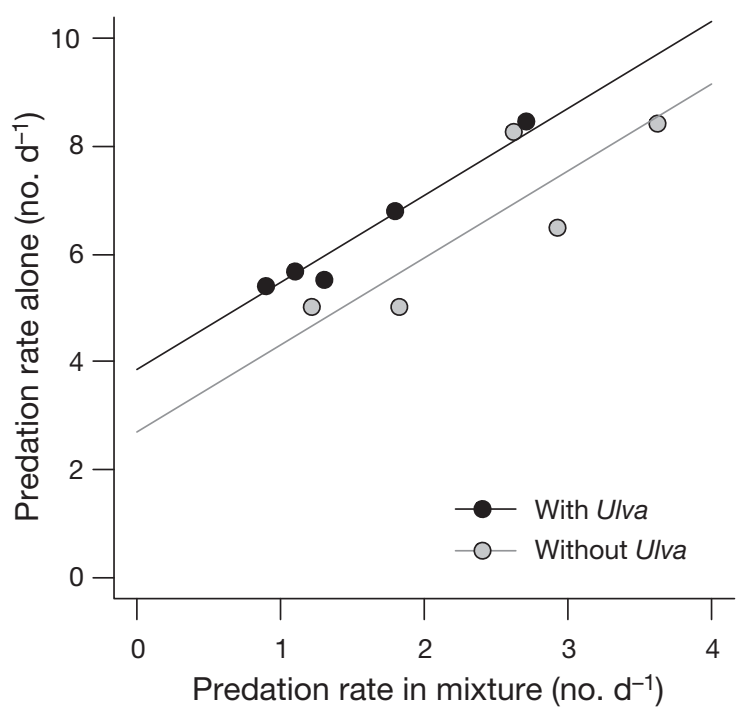

Fig. 2. Predation rate on each of 5 grazer species measured in both grazer mixtures and alone (the 6th species, Ampithoe sectimanus, was not included in the single species trials). For each species, predation is either unaffected by habitat or higher in the absence of Ulva. Points with the same $x$-value are not the same species, so the higher intercept for the Ulva treatment reflects an effect of species rather than an effect of habitat

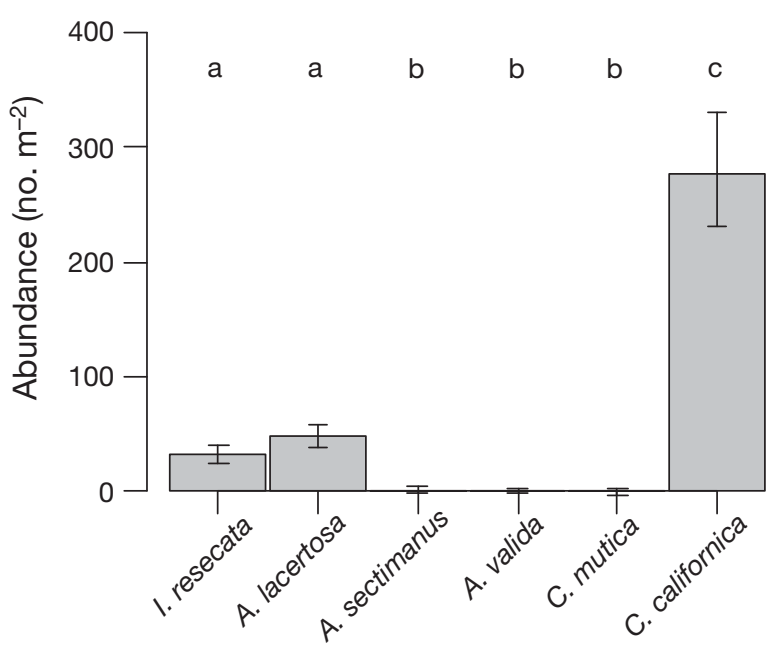

Fig. 3. Average abundance of each species. Abundance was log-transformed for analysis and least squares means were back-transformed. Different letters indicate significant differences between species. Error bars are \pm 1 SE. For full species names see Table 1

\section{Expected trophic cascade effects}

The relative magnitude of trophic cascade effects predicted in this system was substantially decreased by accounting for species-specific grazer variation. Assuming all grazers were equivalent in their feeding preferences and susceptibility to predators, we calculated that predation by 1 additional juvenile cabezon should result in approximately $35 \mathrm{mg}$ more Ulva, $20 \mathrm{mg}$ more eelgrass, or $70 \mu \mathrm{g}$ more microalgal chl a per day (Fig. 4). Accounting for the variation in feeding and predation rates reported here reduced these estimates, as did accounting for differences among species in field abundance. In combination, the expected size of the trophic cascade effect was reduced by $71 \%$ for Ulva, $80 \%$ for eelgrass, and $54 \%$ for microalgae (Fig. 4).

We also found evidence that some major assumptions underlying this analysis are reasonable. First, we evaluated the potential for a trophic cascade for each primary producer separately, which assumes that grazing rates on each food in the field are independent of the availability of other foods. Several lines of evidence support this assumption for at least the most abundant species in this system. Caprella californica fed exclusively on epiphytic microalgae (Fig. 1A-C), so its feeding rate should not depend on eelgrass or Ulva abundance. For Idotea resecata and Ampithoe lacertosa, we found previously that feeding rates for both species on eelgrass and Ulva does not depend on whether or not the grazers have only a 


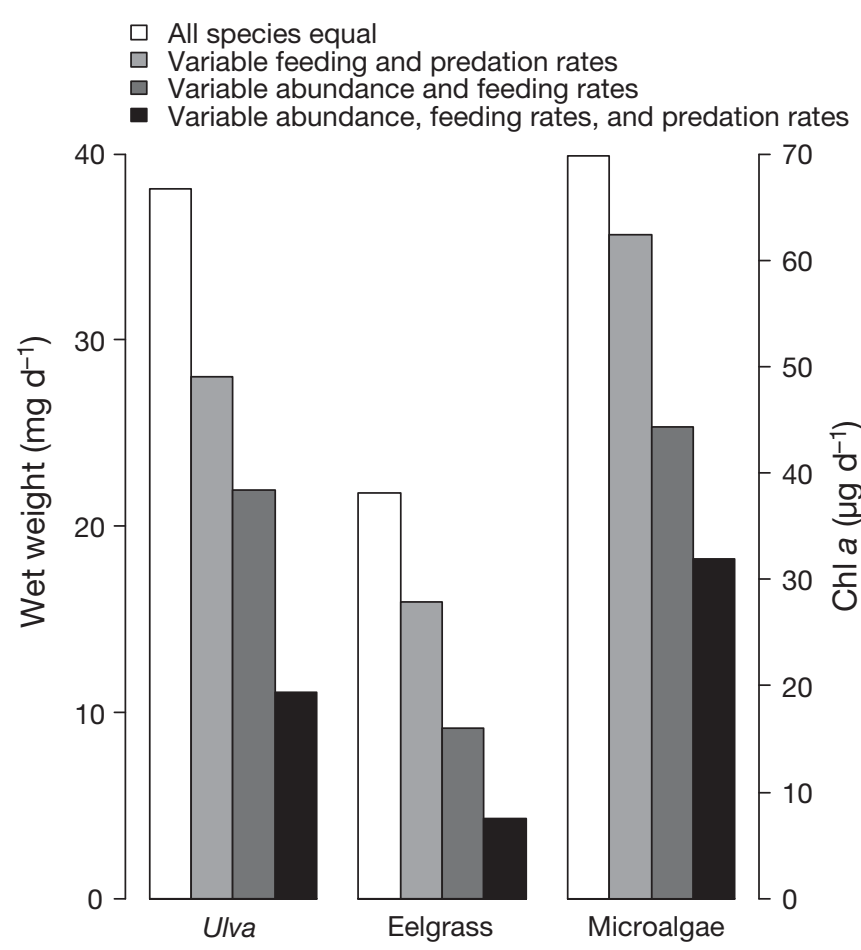

Fig. 4. Expected additional amount of each primary producer resulting from predation by 1 additional fish per day under 4 scenarios of grazer trait variation. Amounts are measured in wet weight for Ulva and eelgrass and in chl a for microalgae. For details of the 4 scenarios see 'Materials and methods: Analysis'

single food or a choice of both (R. Best unpubl. data). In addition, the spatial distributions of the 2 major algal primary producers in our system (Ulva and microalgae) are largely non-overlapping (Fig. 5), such that grazers will rarely have a choice between these 2 foods at any particular place and time.

Second, we assumed that the species-specific predation rates would not depend on the composition of the grazer community which fish would encounter in the field. Whereas our experimental communities consisted of 30 ind. evenly distributed between 6 species, the abundance of these species in the field is not even (Fig. 3). However, predation rates on single grazer species were positively correlated with their predation rates in the mixed-grazer trials (Fig. 2), meaning that relative predation susceptibility may be robust to variation in grazer composition in the field.

Third, we used the average total consumption from the mixed-grazer predation trials (9.4 total individuals consumed with Ulva and 12.9 without Ulva) across all scenarios in this analysis, varying only the proportional contribution of each grazer species to that total according to predation susceptibility and/or

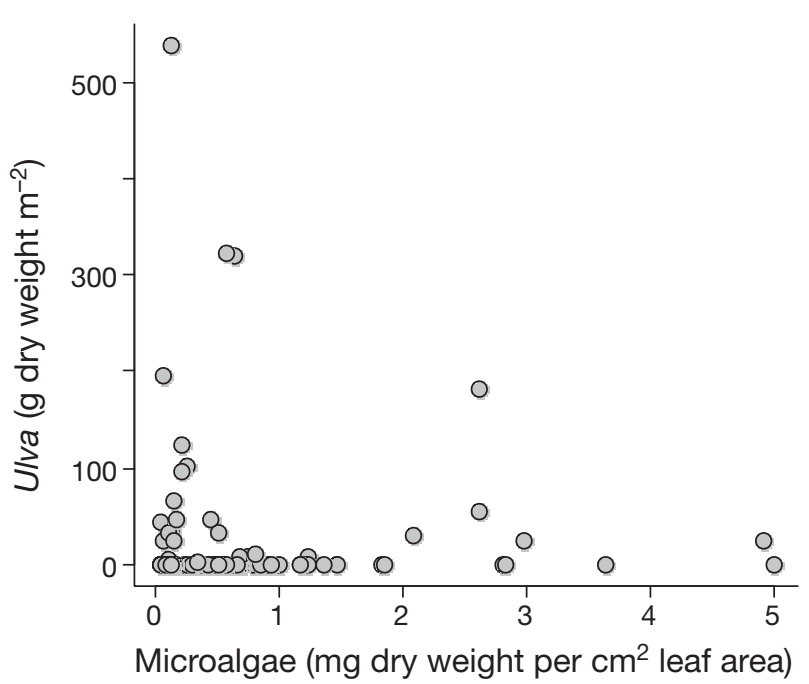

Fig. 5. Abundance of Ulva and microalgae in field samples

relative abundance. This assumes that the total number of grazers consumed per fish per day does not depend on the composition of the grazer community which fish encounter in the field. It is possible, however, that total consumption is actually higher in communities with higher relative abundances of Caprella californica, which might be common in the field (Fig. 3). Higher predation on C. californica should not affect our calculations for Ulva or eelgrass because this species does not consume macrophytes (Fig. 1A,B). For epiphytic microalgae, however, this could lead to a somewhat greater trophic cascade effect than we predict. Further studies of how grazer community composition drives total consumption rates would be helpful in evaluating this assumption.

\section{DISCUSSION}

We found significant variation among grazer species in feeding rates, predation susceptibility, and abundance, with predation pressure skewed towards the least important (per capita) and most abundant consumer (Caprella californica). Thus, the impact of trophic cascades on primary producer abundance in our system should be less than would have been expected without knowledge of grazer variation in feeding rates and predation susceptibility. The high abundance of grazers and invertivorous fishes that consume grazers in seagrass beds makes it logical to conclude that a strong trophic cascade is likely. However, evidence for trophic cascades and top-down control of the grazer trophic level in seagrass systems has so far been mixed (Douglass et al. 2010). If the 
negative correlation between predation susceptibility and grazer impact that we observe occurs in some systems and not others, this may partly explain the variation in results.

Differences in feeding niche among grazers have been demonstrated in several other seagrass and algae systems (Duffy \& Hay 1991, Duffy et al. 2001, Raberg \& Kautsky 2007, Jaschinski \& Sommer 2008), and there are several reasons to think that similar patterns of predation susceptibility may not be unique to our system. Below, we consider the generality of our predictions by examining patterns in grazer population growth, size, and habitat use that may be relevant to other seagrass systems.

\section{Generality of the negative relationship between grazing rates and predation susceptibility}

Of the grazer species in our community, caprellids were the most susceptible to predation. Caprellids are long but very thin (Table 1), cling to eelgrass high in the canopy, sometimes wave back and forth in search of food, and are slow to escape. This behavior appears to make them highly vulnerable to predation. Caine (1991) found that shiner perch Cymatogaster aggregata strike in response to caprellid movement and feed on them almost exclusively, when they are available. Two studies in other habitats used fish gut-content analysis in comparison with surveys of grazer abundance (Page et al. 2007, Vazquez-Luis et al. 2010) and also found that caprellids were selectively consumed to a greater extent than gammarid amphipods. A similar approach in a Florida seagrass system showed that selective feeding on caprellids increased with seagrass density, presumably because other more cryptic species had greater opportunities to hide (Stoner 1979). If caprellids also have weak per capita effects on epiphytic algae in these systems, then predation pressure may be focused on the least important grazers (per capita) wherever caprellids form a substantial fraction of the grazer community. This does not necessarily mean that caprellids as a group are unimportant in controlling seagrass epiphytes; they graze epiphytic algae without damaging eelgrass, and large numbers of individually inefficient grazers can have large effects (Silliman \& Bortolus 2003). It means only that, in comparison to other species, many individual caprellids can be lost to predation before there is a major impact on microalgal abundance.

The persistence of abundant summer caprellid populations in Bodega Bay and other northeastern
Pacific estuaries, despite their predation susceptibility, may be due to a tradeoff between rapid growth rate and predator avoidance, as previously demonstrated with fish predation on dragonflies (McPeek 1998). In our system, caprellids increase more rapidly than other mesograzers at the start of the summer season in Bodega Harbor, while the larger, slower growing, and better camouflaged isopods reach peak abundance a full 2 mo later. This suggests there might be different strategies to deal with predation, with some species having fewer, slower growing, larger individuals with higher feeding rates and lower predation susceptibility, and other species producing greater numbers of individuals that are less efficient grazers per capita and more susceptible to predation but able to grow and reproduce quickly.

While this tradeoff contradicts the notion that larger grazers are more apparent and thus more susceptible to predation (Nelson 1980), previous work reports both positive (Moksnes et al. 2008) and negative (Eriksson et al. 2009) correlations between mesograzer size and predation. In our study, the largest (by length) grazers (Table 1) were found on opposite ends of the predation susceptibility spectrum. This suggests that cryptic morphology or behavior may overwhelm the effects of size on predation susceptibility. In this study and in previous work in this system (Olyarnik 2008, our Fig. 1D,E), tube building in Ulva substantially reduced predation susceptibility for Ampithoe lacertosa, which is by far the largest ampithoid in this system and the fastest consumer of Ulva (Fig. 1A).

In our study, we considered only the effect that fish predation may have on grazer abundance, but predator presence can also change the habitat choices (Wellborn et al. 1996, Resetarits 2001, Vonesh et al. 2009) and consumption rates (Schmitz et al. 1997, Duffy et al. 2005) of existing grazers. For tube-building amphipods that use the macroalgae they consume as a refuge (e.g. Ampithoe lacertosa), there should be little tradeoff between feeding and protection from predators, and predator avoidance might actually serve to concentrate grazers in areas with abundant macroalgae. This should help buffer the system against macroalgal trophic cascades. In habitats with scarcer protection, however, feeding and refuge use may not occur simultaneously, and grazing rates on microalgae could be lower in the presence of fish. If species such as Idotea resecata, the fastest consumer of microalgae, are successful at avoiding predation because they are camouflaged while feeding along eelgrass blades, then behavioral responses to fish presence should be consistent with the abundance-based effects we found. If, on the 
other hand, the grazers that are least susceptible to fish predation only accomplish this via greatly reduced activity that includes reduced feeding rates, this could counteract the effects we found.

The extent to which fish presence changes the relative feeding rates of different grazer species on different primary producers would be an excellent avenue for further research, as would the relative effects of different fish species. Because cabezon consumed the thinner but more visible of the mesograzers in our system, we expect that smaller-gaped fish species may have similar if not more extreme feeding preferences for caprellids and small amphipods. However, other fish species may have additional behavior-induced effects on grazer feeding rates that warrant investigation.

\section{Effects of grazer trait variation on eelgrass itself}

In our system, both Ulva and microalgae compete with eelgrass for light, with Ulva reaching high abundance in shallow areas (over $500 \mathrm{~g}$ dry weight $\mathrm{m}^{-2}$ ) but epiphytic algae present in a greater number of samples (Fig. 5). We have observed both microalgal accumulation and shading from Ulva to reduce eelgrass growth in mesocosms (Hughes et al. 2010; R. Best unpubl. data), and have seen Ulva decrease eelgrass biomass and shoot density in the field (Olyarnik 2008). We found a larger reduction in predicted trophic cascade effect due to grazer trait variation for Ulva (71\%) than for microalgae (54\%). This is because microalgae was consumed by all of the grazer species in our study, including the predation-susceptible caprellids. This does not mean that overgrowth by microalgae is more likely than overgrowth by macroalgae in our system, only that there is less variation among species in their consumption of microalgae. Because of this, in systems where the only threat to seagrass is overgrowth by epiphytic microalgae, accounting for grazer trait variation may have a smaller effect.

The hypothesis that seagrass decline may be due to trophic cascades assumes that small invertebrate grazers feed exclusively on algae, rather than directly on eelgrass, which is true for most but not all grazer species in both our system and others (Heck \& Valentine 2006). The skew in predation pressure towards the slowest consumers of algae should have a positive effect on eelgrass, since predation by fish should not lead to as much additional algae growth as would occur if predation focused on grazers with high per capita grazing rates. However, we also found relatively low vulnerability to predation for the few species that do consume eelgrass, including Idotea resecata and the introduced species Ampithoe valida (Fig. 1E). This means there is also lower potential for cabezon predation to reduce direct consumption of eelgrass than we would expect using average mesograzer grazing and predation rates (Fig. 4). Thus, the skew in predation susceptibility has both positive and negative implications for eelgrass. Eelgrass should face not only a smaller than expected increase in its competitors but also a smaller than expected escape from its own grazers.

\section{Grazer trait variation may help explain weak evidence for trophic cascades in some seagrass systems}

In this study, mesograzer variation in feeding niche, predation susceptibility, abundance, and distribution all contributed to a decrease in the expected strength of the trophic cascade. Furthermore, there are reasons to expect that the same pattern could be important in some other seagrass systems. The same grazer community is found in several estuaries along the west coast of North America, and caprellids in particular may play a similar role. They appear to be important fish food in many systems (Stoner 1979, Caine 1991, Page et al. 2007, Vazquez-Luis et al. 2010), generally do not consume macrophytes (Caine 1977, Guerra-García \& Tierno de Figueroa 2009), and have slow feeding rates on epiphytes. They may therefore absorb a substantial fraction of predation pressure with little effect on lower trophic levels. At the other end of our grazer spectrum, the ampithoids represent a large and diverse family of grazers that are common components of seagrass systems globally (Poore et al. 2008) and may be widely protected from predation by their behavior of building tubes within their food plants (Duffy \& Hay 1994).

Previous studies have explained the lower than expected strength of trophic cascades as a consequence of omnivory (Persson 1999) or the broad taxonomic class (e.g. vertebrate vs. invertebrate) of predator and herbivore (Borer et al. 2005), but much more attention may need to be paid to variation in traits among species within a trophic level. As others have noted, this requires that we collect data on the relative abundance of herbivores by size and species rather than gross trophic level biomass (Persson 1999, Moksnes et al. 2008). In combination, we also need further research on the potential tradeoffs between life history, morphology, and behavior that determine the ecolog- 
ical roles played by particular widespread taxonomic groups. Given these data, we can better predict the proportion of grazer species in seagrass systems globally that are both important consumers and highly susceptible to predation, the dual criteria necessary for strong trophic cascades to occur.

Acknowledgements. We thank S. Williams for use of laboratory equipment and feedback on experimental design, and S. Wheeler and J. Hobbs for feedback on fish community composition, as well as help in the field. We thank E. Hinman, E. Morrison, and E. Potter for laboratory assistance. This project was supported by a Fulbright Science and Technology PhD Award and the University of California Davis Center for Population Biology (grants to R.J.B.) and is a contribution of the Bodega Marine Laboratory, UC Davis.

\section{LITERATURE CITED}

Baden S, Bostrom C, Tobiasson S, Arponen H, Moksnes PO (2010) Relative importance of trophic interactions and nutrient enrichment in seagrass ecosystems: a broadscale field experiment in the Baltic-Skagerrak area. Limnol Oceanogr 55:1435-1448

> Bascompte J, Melian CJ, Sala E (2005) Interaction strength combinations and the overfishing of a marine food web. Proc Natl Acad Sci USA 102:5443-5447

Borer ET, Seabloom EW, Shurin JB, Anderson KE and others (2005) What determines the strength of a trophic cascade? Ecology 86:528-537

Bozdech M (2004) Spatial and temporal eelgrass community structure in Bodega Harbor. Student report, University of California, Davis. Available from Bodega Marine Lab Library, Bodega Bay, CA

$>$ Bronmark C, Klosiewski SP, Stein RA (1992) Indirect effects of predation in a freshwater, benthic food chain. Ecology 73:1662-1674

> Bruno JF, O'Connor MI (2005) Cascading effects of predator diversity and omnivory in a marine food web. Ecol Lett 8: 1048-1056

Caine EA (1977) Feeding mechanisms and possible resource partitioning of the caprellidae (Crustacea:Amphipoda) from Puget Sound, USA. Mar Biol 42:331-336

Caine EA (1991) Caprellid amphipods: fast food for the reproductively active. J Exp Mar Biol Ecol 148:27-33

Conover WJ, Iman RL (1981) Rank transformations as a bridge between parametric and nonparametric statistics. Am Stat 35:124-129

Douglass JG, France KE, Richardson JP, Duffy JE (2010) Seasonal and interannual change in a Chesapeake Bay eelgrass community: insights into biotic and abiotic control of community structure. Limnol Oceanogr 55: $1499-1520$

Dowd SL (2006) Temporal and spatial variation of fish populations in eelgrass communities of Bodega Bay. Student report, University of California, Davis. Available from Bodega Marine Lab Library, Bodega Bay, CA

> Duffy JE, Harvilicz AM (2001) Species-specific impacts of grazing amphipods in an eelgrass-bed community. Mar Ecol Prog Ser 223:201-211

Duffy JE, Hay ME (1991) Amphipods are not all created equal: a reply to Bell. Ecology 72:354-358
Duffy JE, Hay ME (1994) Herbivore resistance to seaweed chemical defense: the roles of mobility and predation risk. Ecology 75:1304-1319

> Duffy JE, Macdonald KS, Rhode JM, Parker JD (2001) Grazer diversity, functional redundancy, and productivity in seagrass beds: an experimental test. Ecology 82: 2417-2434

- Duffy JE, Richardson JP, France KE (2005) Ecosystem consequences of diversity depend on food chain length in estuarine vegetation. Ecol Lett 8:301-309

Eriksson BK, Ljunggren L, Sandstrom A, Johansson G and others (2009) Declines in predatory fish promote bloomforming macroalgae. Ecol Appl 19:1975-1988

Eriksson B, van Sluis C, Sieben K, Kautsky L, Råberg S (2010) Omnivory and grazer functional composition moderate cascading trophic effects in experimental Fucus vesiculosus habitats. Mar Biol 158:747-756

> Finke DL, Denno RF (2005) Predator diversity and the functioning of ecosystems: the role of intraguild predation in dampening trophic cascades. Ecol Lett 8:1299-1306

Gacia E, Littler MM, Littler DS (1999) An experimental test of the capacity of food web interactions (fish-epiphytesseagrasses) to offset the negative consequences of eutrophication on seagrass communities. Estuar Coast Shelf Sci 48:757-766

Guerra-García J, Tierno de Figueroa J (2009) What do caprellids (Crustacea: Amphipoda) feed on? Mar Biol 156:1881-1890

- Heck KL Jr, Valentine JF (2006) Plant-herbivore interactions in seagrass meadows. J Exp Mar Biol Ecol 330:420-436

Heck KL, Valentine JF (2007) The primacy of top-down effects in shallow benthic ecosystems. Estuar Coast 30: 371-381

Heck KL, Pennock JR, Valentine JF, Coen LD, Sklenar SA (2000) Effects of nutrient enrichment and small predator density on seagrass ecosystems: an experimental assessment. Limnol Oceanogr 45:1041-1057

> Heck KL Jr, Valentine JF, Pennock JR, Chaplin G, Spitzer PM (2006) Effects of nutrient enrichment and grazing on shoalgrass Halodule wrightii and its epiphytes: results of a field experiment. Mar Ecol Prog Ser 326:145-156

Hemminga MA, Duarte CM (2000) Seagrass ecology. Cambridge University Press, Cambridge

Hughes AR, Bando KJ, Rodriguez LF, Williams SL (2004) Relative effects of grazers and nutrients on seagrasses: a meta-analysis approach. Mar Ecol Prog Ser 282:87-99

Hughes AR, Best RJ, Stachowicz JJ (2010) Genotypic diversity and grazer identity interactively influence seagrass and grazer biomass. Mar Ecol Prog Ser 403:43-51

> Iman RL, Hora SC, Conover WJ (1984) Comparison of asymptotically distribution-free procedures for the analysis of complete blocks. J Am Stat Assoc 79:674-685

> Jaschinski S, Sommer U (2008) Functional diversity of mesograzers in an eelgrass-epiphyte system. Mar Biol 154: 475-482

Lewis L (2002) Feeding habits and growth of juvenile cabezon (Scorpaenichthys marmoratus) in the eelgrass beds of Bodega Harbor, California. Student report, University of California, Davis. Available from Bodega Marine Lab Library, Bodega Bay, CA

Littell R, Milliken G, Stroup W, Wolfinger R, Schabenberger O (1996) SAS system for mixed models. SAS Press, Cary, NC

Lockwood JR III (1998) On the statistical analysis of multiple-choice feeding preference experiments. Oecologia 116:475-481 
Martin TH, Crowder LB, Dumas CF, Burkholder JM (1992) Indirect effects of fish on macrophytes in Bays Mountain Lake: evidence for a littoral trophic cascade. Oecologia 89:476-481

McGlathery KJ (2001) Macroalgal blooms contribute to the decline of seagrass in nutrient-enriched coastal waters. J Phycol 37:453-456

McPeek MA (1998) The consequences of changing the top predator in a food web: a comparative experimental approach. Ecol Monogr 68:1-23

Moksnes PO, Gullstrom M, Tryman K, Baden S (2008) Trophic cascades in a temperate seagrass community. Oikos 117:763-777

Nelson WG (1979) Experimental studies of selective predation on amphipods: consequences for amphipod distribution and abundance. J Exp Mar Biol Ecol 38:225-245

Nelson WG (1980) A comparative study of amphipods in seagrasses from Florida to Nova Scotia. Bull Mar Sci 30: 80-89

Olyarnik SV (2008) The causes and consequences of macroalgal blooms on an eelgrass (Zostera marina) community in Bodega Harbor, CA. PhD thesis, University of California, Davis, CA

Orth RJ, Carruthers TJB, Dennison WC, Duarte CM and others (2006) A global crisis for seagrass ecosystems. Bioscience 56:987-996

Page HM, Dugan JE, Schroeder DM, Nishimoto MM, Love MS, Hoesterey JC (2007) Trophic links and condition of a temperate reef fish: comparisons among offshore oil platform and natural reef habitats. Mar Ecol Prog Ser 344: 245-256

Parsons TR, Maita Y, Lalli CM (1984) A manual of chemical and biological methods for seawater analysis. Pergamon Press, Oxford

Persson L (1999) Trophic cascades: abiding heterogeneity and the trophic level concept at the end of the road. Oikos 85:385-397

Poore AGB, Hill NA, Sotka EE (2008) Phylogenetic and geographic variation in host breadth and composition by herbivorous amphipods in the family Ampithoidae. Evolution 62:21-38

Power ME (1990) Effects of fish in river food webs. Science 250:811-814

Prado P, Heck KL Jr (2011) Seagrass selection by omnivorous and herbivorous consumers: determining factors. Mar Ecol Prog Ser 429:45-55

Raberg S, Kautsky L (2007) Consumers affect prey biomass and diversity through resource partitioning. Ecology 88: 2468-2473

Resetarits WJ (2001) Colonization under threat of predation: avoidance of fish by an aquatic beetle, Tropisternus lateralis (Coleoptera: Hydrophilidae). Oecologia 129: $155-160$

SAS Institute (2008) SAS for Windows 9.2, Cary NC

> Schmitz OJ, Beckerman AP, O'Brien KM (1997) Behaviorally mediated trophic cascades: effects of predation risk on food web interactions. Ecology 78:1388-1399

Sieben K, Ljunggren L, Bergström U, Eriksson BK (2011) A meso-predator release of stickleback promotes recruitment of macroalgae in the Baltic sea. J Exp Mar Biol Ecol 397:79-84

Silliman BR, Bortolus A (2003) Underestimation of Spartina productivity in western Atlantic marshes: marsh invertebrates eat more than just detritus. Oikos 101:549-554

Stoner AW (1979) Species-specific predation on amphipod Crustacea by the pinfish Lagodon rhomboides: mediation by macrophyte standing crop. Mar Biol 55: 201-207

Valentine JF, Duffy C (2006) The central role of grazing in seagrass ecology. In: Larkum AWD, Orth RJ, Duarte CM (eds) Seagrasses: biology, ecology and conservation. Springer, Dordrecht, p 463-501

> Valiela I, McClelland J, Hauxwell J, Behr PJ, Hersh D, Foreman K (1997) Macroalgal blooms in shallow estuaries: controls and ecophysiological and ecosystem consequences. Limnol Oceanogr 42:1105-1118

Vazquez-Luis M, Sanchez-Jerez P, Bayle-Sempere JT (2010) Effects of Caulerpa racemosa var. cylindracea on prey availability: an experimental approach to predation of amphipods by Thalassoma pavo (Labridae). Hydrobiologia 654:147-154

Vonesh J, Kraus J, Rosenberg S, Chase J (2009) Predator effects on aquatic community assembly: disentangling the roles of habitat selection and post-colonization processes. Oikos 118:1219-1229

Waycott M, Duarte C, Carruthers T, Orth R and others (2009) Accelerating loss of seagrasses across the globe threatens coastal ecosystems. Proc Natl Acad Sci USA 106: 12377-12381

> Wellborn GA, Skelly DK, Werner EE (1996) Mechanisms creating community structure across a freshwater habitat gradient. Annu Rev Ecol Syst 27:337-363

> Wilson JR, Broitman BR, Caselle JE, Wendt DE (2008) Recruitment of coastal fishes and oceanographic variability in central California. Estuar Coast Shelf Sci 79: 483-490

Yip C (2006) Cascading effects of mesograzers on the epiphyte communities of Zostera marina. Student report, University of California, Davis. Available from Bodega Marine Lab Library, Bodega Bay, CA 
Appendix 1. Sample calculation of expected trophic cascade effects

Calculations used for comparing the trophic cascade effect on Ulva abundance under different scenarios of grazer trait variation. In each case, we calculate the additional amount of Ulva expected to remain in the system due to removal of herbivores by predation by 1 juvenile cabezon in $1 \mathrm{~d}$. These calculations produce the 4 bars in the first column of Fig. 4 . Table A1 shows species-specific and average rates, with each column labeled with a letter. These letters are then used to indicate the data used in calculations for each scenario (Table A2). The calculations involved the following steps: (1) Determine how many of each of the 6 grazer species would be eaten per day. (2) Multiply the number eaten by that species' daily per-capita feeding rate. This gives the total amount of Ulva no longer eaten by that species. (3) Sum these products across all 6 species.

Thus, under a scenario without grazer trait variation (Scenario 1), we predict that 1 cabezon would increase the amount of Ulva present in our system by $38.2 \mathrm{mg}$ per day. In contrast, including all sources of trait variation we predict the increase in algae to be only $11.1 \mathrm{mg}$, a $71 \%$ decrease from 38.2

Table A1. Data

\begin{tabular}{|lcccc|}
\hline Grazer species & $\begin{array}{c}\text { Predation rate } \\
\left(\mathrm{no.}^{-1}\right)\end{array}$ & $\begin{array}{c}\text { Feeding rate on Ulva } \\
\left(\mathrm{mg} \mathrm{d}^{-1}\right)\end{array}$ & $\begin{array}{c}\text { Abundance } \\
\left(\mathrm{no.}^{-2}\right)\end{array}$ & $\begin{array}{c}\text { Proportional abundance } \\
(\text { sums to 1) }\end{array}$ \\
\hline Idotea resecata & $\mathbf{A}$ & $\mathbf{C}$ & $\mathbf{E}$ & $\mathbf{F}$ \\
Caprella californica & 1.3 & 5.5 & 31.8 & 0.1 \\
Caprella mutica & 2.7 & 0.1 & 276.6 & 0.8 \\
Ampithoe lacertosa & 1.8 & 0.5 & 0.0 & 0.0 \\
Ampithoe sectimanus & 1.1 & 13.3 & 47.4 & 0.1 \\
Ampithoe valida & 1.2 & 2.1 & 0.0 & 0.0 \\
Total & 0.9 & 2.9 & & 1.0 \\
& 9.4 & & & \\
Average & $\mathbf{B}$ & $\mathbf{D}$ & & \\
& 1.6 & 4.1 & & \\
\hline
\end{tabular}

Table A2. Calculations

\begin{tabular}{|c|c|c|c|c|c|c|c|}
\hline $\begin{array}{l}\text { Scenario 1: } \\
\text { All species equal }\end{array}$ & $\begin{array}{l}\text { No. } \\
\text { eaten } \\
\text { B }\end{array}$ & $\begin{array}{l}\text { Feeding } \\
\text { rate } \\
\text { D }\end{array}$ & $\begin{array}{l}\text { No. eaten } \times \\
\text { feeding } \\
\text { rate }\end{array}$ & $\begin{array}{l}\text { Scenario 3: } \\
\text { Variable abundance } \\
\text { and feeding rates }\end{array}$ & $\begin{array}{c}\text { No. } \\
\text { eaten } \\
\mathrm{F} \times 9.4^{\mathrm{a}}\end{array}$ & $\begin{array}{l}\text { Feeding } \\
\text { rate } \\
\quad \mathrm{C}\end{array}$ & $\begin{array}{l}\text { No. eaten } \times \\
\text { feeding rate }\end{array}$ \\
\hline Idotea resecata & 1.6 & 4.1 & 6.4 & Idotea resecata & 0.8 & 5.5 & 4.6 \\
\hline Caprella californica & 1.6 & 4.1 & 6.4 & Caprella californica & 7.3 & 0.1 & 0.7 \\
\hline Caprella mutica & 1.6 & 4.1 & 6.4 & Caprella mutica & 0.0 & 0.5 & 0.0 \\
\hline Ampithoe lacertosa & 1.6 & 4.1 & 6.4 & Ampithoe lacertosa & 1.2 & 13.3 & 16.6 \\
\hline Ampithoe sectimanus & 1.6 & 4.1 & 6.4 & Ampithoe sectimanus & 0.0 & 2.1 & 0.1 \\
\hline Ampithoe valida & 1.6 & 4.1 & 6.4 & Ampithoe valida & 0.0 & 2.9 & 0.0 \\
\hline Total & 9.4 & & $38.2 \mathrm{mg} \mathrm{d}^{-1}$ & Total & 9.4 & & $22.0 \mathrm{mg} \mathrm{d}^{-1}$ \\
\hline $\begin{array}{l}\text { Scenario 2: } \\
\text { Variable feeding } \\
\text { and predation rates }\end{array}$ & $\begin{array}{l}\text { No. } \\
\text { eaten } \\
\text { A }\end{array}$ & $\begin{array}{l}\text { Feeding } \\
\text { rate } \\
\text { C }\end{array}$ & $\begin{array}{l}\text { No. eaten } \times \\
\text { feeding } \\
\text { rate }\end{array}$ & $\begin{array}{l}\text { Scenario 4: } \\
\text { Variable abundance, } \\
\text { feeding rates, and } \\
\text { predation rates }\end{array}$ & $\begin{array}{l}\text { No. } \\
\text { eaten } \\
(\mathrm{A} \times \mathrm{F}) \times \\
4 / \Sigma(\mathrm{A} \times \mathrm{F})]^{\mathrm{b}}\end{array}$ & $\begin{array}{l}\text { Feeding } \\
\text { rate } \\
\mathrm{C}\end{array}$ & $\begin{array}{l}\text { No. eaten } \times \\
\text { feeding rate }\end{array}$ \\
\hline Idotea resecata & 1.3 & 5.5 & 7.1 & Idotea resecata & 0.5 & 5.5 & 2.5 \\
\hline Caprella californica & 2.7 & 0.1 & 0.3 & Caprella californica & 8.3 & 0.1 & 0.8 \\
\hline Caprella mutica & 1.8 & 0.5 & 0.9 & Caprella mutica & 0.0 & 0.5 & 0.0 \\
\hline Ampithoe lacertosa & 1.1 & 13.3 & 14.7 & Ampithoe lacertosa & 0.6 & 13.3 & 7.8 \\
\hline Ampithoe sectimanus & 1.2 & 2.1 & 2.5 & Ampithoe sectimanus & 0.0 & 2.1 & 0.0 \\
\hline Ampithoe valida & 0.9 & 2.9 & 2.6 & Ampithoe valida & 0.0 & 2.9 & 0.0 \\
\hline Total & 9.4 & & $28.0 \mathrm{mg} \mathrm{d}^{-1}$ & Total & 9.4 & & $11.1 \mathrm{mg} \mathrm{d}^{-1}$ \\
\hline
\end{tabular}

